\title{
Unearthing The Alleviatory Mechanisms of Hydrogen Sulfide in Aluminum Toxicity in Rice
}

\section{Chun Quan Zhu}

China National Rice Research Institute

\section{Wen Jun Hu}

Zhejiang Academy of Agricultural Sciences

\section{QianQian Wei}

Anhui University

\section{Hui Zhang}

Jiangsu Academy of Agricultural Sciences

\section{Xiao Chuang Cao}

China National Rice Research Institute

\section{Lian Feng Zhu}

China National Rice Research Institute

\section{Ya Li Kong}

China National Rice Research Institute

\section{Xing Jia Xiang}

Anhui University

Jia Liu

Jiangxi Academy of Agricultural Sciences

\section{Qian Yu Jin}

China National Rice Research Institute

Junhua Zhang ( $\nabla$ zhangjunhua@caas.cn )

China National Rice Research Institute https://orcid.org/0000-0003-4198-8353

\section{Research Article}

Keywords: H2S, Al toxicity, ethylene, rice, transcriptomics, molecular mechanisms

Posted Date: June 28th, 2021

DOI: https://doi.org/10.21203/rs.3.rs-644066/v1

License: @ (i) This work is licensed under a Creative Commons Attribution 4.0 International License. Read Full License

Version of Record: A version of this preprint was published at Plant Physiology and Biochemistry on April 1st, 2022. See the published version at https://doi.org/10.1016/j.plaphy.2022.04.006. 


\section{Abstract}

Hydrogen sulfide $\left(\mathrm{H}_{2} \mathrm{~S}\right)$ improves aluminum (Al) resistance in rice; however, the underlying molecular mechanism remains unclear. In the present study, treatment with $30-\mu \mathrm{M}$ Al significantly inhibited rice root growth and increased the total Al content and apoplastic and cytoplasm Al concentration in the rice roots. However, pretreatment with $\mathrm{NaHS}_{2}\left(\mathrm{H}_{2} \mathrm{~S}\right.$ donor) reversed these negative effects. Transcriptomics and physiological experiments confirmed that $\mathrm{H}_{2} \mathrm{~S}$ increased the ATP, sucrose, glutathione, and ascorbic acid contents, which was accompanied by decreased $\mathrm{O}_{2}{ }^{-\cdots}$ and $\mathrm{H}_{2} \mathrm{O}_{2}$ contents, to alleviate Al toxicity. $\mathrm{H}_{2} \mathrm{~S}$ significantly inhibited ethylene emissions in the rice and then inhibited pectin synthesis and increased the pectin methylation degree to reduce cell wall Al deposition. The phytohormones indole-3-acetic and brassinolide were also involved in the alleviation of Al toxicity by $\mathrm{H}_{2} \mathrm{~S}$. In addition, other pathways of material and energy metabolism, secondary metabolism, cell wall components, signal transduction, and transcriptional and translational pathways in the rice roots were also regulated by $\mathrm{H}_{2} \mathrm{~S}$ under $\mathrm{Al}$ toxicity conditions. These findings improve our understanding of how $\mathrm{H}_{2} \mathrm{~S}$ affects rice responses to Al toxicity, which will facilitate further studies on crop safety.

\section{Introduction}

Hydrogen sulfide $\left(\mathrm{H}_{2} \mathrm{~S}\right)$ is an important endogenous gasotransmitter that maintains a dynamic equilibrium with Lcysteine desulfhydrase, D-cysteine desulfhydrase, sulphite reductase, cyanoalanine synthase, cysteine synthase, and Oacetyl-I-serine(thiol)lyase in plants (Banerjee et al., 2018; Li, 2013; Sirko et al., 2004; Tai and Cook, 2000). Although a high $\mathrm{H}_{2} \mathrm{~S}$ concentration is harmful to plant growth, the appropriate $\mathrm{H}_{2} \mathrm{~S}$ concentrations acts as signaling molecule to regulate plant development and the response to environmental stress (Yamasaki and Cohen, 2016). For example, $\mathrm{H}_{2} \mathrm{~S}$ induces protein persulfidation to protect plants from oxidative damage (Filipovic, 2015), maintains a higher $\mathrm{K}^{+} / \mathrm{Na}^{+}$ratio to ameliorate salt stress (Wang et al., 2012), reduces peroxidation damage to promote wheat seed germination under drought stress (Zhang et al., 2010c), and reduces electrolyte leakage in tobacco (Nicotiana tabacum L.) suspensioncultured cells to alleviate heat stress (Li et al., 2012b).

The amelioratory roles of $\mathrm{H}_{2} \mathrm{~S}$ on heavy metal stress in plants have been demonstrated in many studies (Liu et al., 2015; Rizwan et al., 2019; Singh et al., 2015; Zhang et al., 2010a; Zhang et al., 2008). The application of NaHS significantly enhanced the AsA-GSH cycle to alleviate As toxicity in pea seedlings (Singh et al., 2015), promoted the protoplast sequestering of $\mathrm{Cd}$ in Arabidopsis (Guan et al., 2018), boosted photosynthesis to alleviate Ni toxicity in rice, and reduced peroxidation damage to alleviate $\mathrm{Cr}$, Cu, and $\mathrm{Zn}$ toxicity (Rizwan et al., 2019). About $30 \%-50 \%$ of arable land in the world is acidic and has limited crop production capacity due to Al toxicity (He et al., 2012). $\mathrm{H}_{2} \mathrm{~S}$ is involved in alleviating Al toxicity in plants. For example, treatment with NaHS significantly increased the germination of wheat seedlings (Zhang et al., 2010b), enhanced citrate secretion and inhibited reactive oxygen species (ROS) bursts in barely seedlings, enhanced the translocation of Al from the cytoplasm to the vacuole and reduced cell wall Al deposition in rice (Chen et al., 2013a; Dawood et al., 2012; Zhu et al., 2018). However, research into the mechanism by which $\mathrm{H}_{2} \mathrm{~S}$ alleviates Al toxicity has mainly focused on the physiological level, while the molecular mechanisms remain unclear.

Recently, transcriptomics has been used to explore Al response genes in plants; for instance, the possible transporter genes involved in Al resistance in buckwheat leaves were found following treatment with short-term moderate Al stress (Yokosho et al., 2014). In the present study, seedlings of the rice cultivar "Kasalath" were pretreated with or without the $\mathrm{H}_{2} \mathrm{~S}$ donor $\mathrm{NaHS}$ under Al toxicity conditions for one day, and the roots were collected for genome-wide transcriptome and physiological analysis.

\section{Materials And Methods}


The seeds of the indica rice "Kasalath" were soaked in distilled water for $24 \mathrm{~h}$ and then transferred to $0.5-\mathrm{mM} \mathrm{CaCl}_{2}$ solution ( $\mathrm{pH} 5.6$ ) at $30^{\circ} \mathrm{C}$ under total darkness. The rice seedlings were treated with or without $2 \mu \mathrm{M}$ of the $\mathrm{H}_{2} \mathrm{~S}$ donor $\mathrm{NaHS}$ in $0.5-\mathrm{mM} \mathrm{CaCl}_{2}$ solution $(\mathrm{pH} 5.6$ ) until the rice roots reached about $1 \mathrm{~cm}$. After $8 \mathrm{~h}$ of treatment, the solution was discarded, and the roots were treated with or without $30-\mu \mathrm{M} \mathrm{Al}\left(\mathrm{AlCl}_{3} \cdot 6 \mathrm{H}_{2} \mathrm{O}\right)$ in $0.5-\mathrm{mM} \mathrm{CaCl} \mathrm{C}_{2}$ solution $(\mathrm{pH} 4.5)$. The treatments were set as $\mathrm{CK}$ (without $\mathrm{NaHS}$ and $\mathrm{Al}$ treatment), $\mathrm{H}_{2} \mathrm{~S}$ (only treated with $\mathrm{NaHS}$ ), $\mathrm{Al}$ (only treated with $\mathrm{Al}$ ), and $\mathrm{Al}+\mathrm{H}_{2} \mathrm{~S}$ (treated with $\mathrm{NaHS}$ and $\mathrm{Al}$ ). After $24 \mathrm{~h}$ of treatment, the fresh roots were collected and frozen in liquid nitrogen immediately. The root lengths were measured before and after Al treatment.

\section{Measurement of Al content in rice}

The fresh roots were collected and dried in the oven to the point where the weight no longer changed. The dry roots $(0.1$ g) were digested in $2 \mathrm{~mL}$ of $\mathrm{HNO}_{3}: \mathrm{HClO}_{4}(v \cdot v, 4: 1)$ at $120^{\circ} \mathrm{C}$ and then diluted to $50 \mathrm{~mL}$ with ultrapure water to measure the total Al content (Shen et al., 2002). The rice root tips $(1 \mathrm{~cm}$ ) were then placed into $1.5-\mathrm{mL}$ ultra-free MC tubes (Millipore, Billerica, MA, USA) and stored at $-80^{\circ} \mathrm{C}$ for $1 \mathrm{~d}$, following which they were heated at $25^{\circ} \mathrm{C}$ to break the cells. The residues after centrifugation were used to extract an apoplastic solution with $1 \mathrm{~mL}$ of 2-M HCl. The Al concentrations were measured by inductively coupled plasma mass spectrometry (ICP-MS).

The cytoplasmic Al content was indicated by the intensity of the green fluorescence after staining with morin. One centimeter of the rice root tip was collected and stained in $0.01 \%$ morin for $30 \mathrm{~min}$ at room temperature, and the extra dye was washed off using deionized water. Images were captured using a fluorescence microscope (LEICA DM2500) (Li et al., 2016).

\section{Transcriptome library construction, sequencing, and bioinformatics analysis}

The total RNA was extracted by TRIzol reagent (Invitrogen, Germany) according to the manufacturer's instructions. The RNA, which met the experimental requirements, was enriched by Oligo(dT) beads and reverse transcribed to cDNA immediately after fragmenting into short fragments. The synthesis of second-strand cDNA, purification of cDNA fragments, amplification of cDNA, and sequencing by Illumina HiSeq ${ }^{\mathrm{TM}} 2500$ were completed by Gene Denovo Biotechnology Co. (Guangzhou, China) according to Yang et al. (2021). Reads were mapped to the ribosome RNA (rRNA) database by Bowtie2 (Langmead and Salzberg, 2012). TopHat2 was used to map the rRNA removed reads (version 2.0.3.12) (Kim et al., 2013a). Unmapped reads were then re-aligned with Bowtie2 and split into smaller segments (Trapnell et al., 2010). The reconstruction of transcripts was carried out with the Cufflinks software (Trapnell et al., 2012), which together with TopHat2 allowed for the identification of new genes and new splice variants of known genes.

The RSEM software was used to quantify gene abundances (Li and Dewey, 2011), and the FPKM (Fragments Per Kilobase of transcript per Million mapped reads) method was used to normalize the gene expression levels. To identify differentially expressed genes (DEGs) across samples or groups, the edgeR package (http://www.rproject.org/) was used. We identified genes with a fold change $\log _{2}(\mathrm{fc}) \geq 1$ and $P<0.05$ in a comparison as a significant DEG. The Gene Ontology (GO) annotation (https://www.ebi.ac.uk/GOA/) and the Kyoto Encyclopedia of Genes and Genomes (KEGG) pathway analysis (https://www.kegg.jp/kegg/pathway.html) were used to analyze gene functions and enrichment.

\section{Measurement of sucrose and ATP content}

Fresh rice roots $(0.1 \mathrm{~g})$ were ground with $1 \mathrm{~mL}$ of $0.83-\mathrm{M}$ cold perchloric acid (Sigma Aldrich, St. Louis, USA) on ice, and the supernatant was adjusted to a neutral $\mathrm{pH}$ with 3-M KOH . The BacTiter-Glo Microbial Cell Viability Assay (Promega, Madison, USA) was used to determine the ATP concentration in a white opaque-walled 96-well microplate (Greiner BioOne, Frickenhausen, Germany) (Köpnick et al., 2018). 
The rice roots were dried in the oven and ground into powder. The sucrose was extracted with $80 \%$ ethanol and measured using the resorcinol hydrochloric acid method (Li et al., 2012a).

\section{Measurement of pectin demethylesterification degree}

The extraction method of pectin and the concentration of pectin and methanol in the solution were in accordance with a previous study. The degree of pectin demethylesterification was calculated as (1-methanol concentration/pectin concentration) $\times 100 \%$ (Zhu et al., 2020).

\section{Phytohormone measurement}

Ethylene emissions: about $2 \mathrm{~g}$ of fresh roots were incubated in $20-\mathrm{mL}$ glass vials sealed with a silica gel plug at $30^{\circ} \mathrm{C}$ for $2 \mathrm{~h}$ to collect the ethylene released from the roots. Then, $10 \mathrm{~mL}$ of incubated gas was injected into a gas chromatograph (GC-2010 Plus, SHIMADZU) to measure the ethylene concentration (Yu et al., 2016).

Indole-3-acetic acid (IAA) content measurement: fresh roots (about $0.5 \mathrm{~g}$ ) were ground with liquid nitrogen and extracted with $80 \%(v / v)$ methanol. The extraction solution was filtered through a $0.22-\mu \mathrm{M}$ membrane filter, and the IAA concentration was assayed by gas chromatography-mass spectrometry (GC-MS) (Zhou et al., 2010).

Brassinolide (BL) content measurement: the fresh roots (about $0.5 \mathrm{~g}$ ) were ground with liquid nitrogen and extracted with $80 \%(\mathrm{~V} / \mathrm{V})$ methanol at $4^{\circ} \mathrm{C}$ for $2 \mathrm{~h}$ and then extracted through a Brond Elut and Strata-X column. The final extract was filtered through a $0.22-\mu \mathrm{M}$ filter. The BL concentration was measured according to the method described by Bajguz et al. (2011).

\section{Measurement of $\mathrm{GSH}, \mathrm{AsA}, \mathrm{O}_{2}-$; and $\mathrm{H}_{2} \mathrm{O}_{2}$ content}

The glutathione (GSH) was extracted in $80 \%$ ethanol $(\mathrm{v} / \mathrm{v})$ containing $0.15-\mathrm{mM}$ EDTA from $0.1 \mathrm{~g}$ of fresh rice roots and measured by a complex formed by the reaction of DTNB and GSH with a characteristic absorption peak at $412 \mathrm{~nm}$ (Sun et al., 2020).

The ascorbic acid was extracted in $15 \%$ metaphosphoric acid from $0.1 \mathrm{~g}$ of fresh rice roots and measured using a highperformance liquid chromatography (HPLC; Nanospace SI-1, Shiseido, Japan) system equipped with a PDA Detector (Thermo Fisher, Oklahoma, USA) at 254 nm (Muthusamy et al., 2019).

The content of $\mathrm{O}_{2}-$ was indicated by the intensity of red fluorescence after staining with dihydroethidium according to the manufacturer's instructions (S0063, Beyotime, China). The 1-cm rice root tips were collected and stained in 1- $\mu \mathrm{M}$ dihydroethidium for $30 \mathrm{~min}$ at room temperature, and the extra dye was washed off using deionized water. The fluorescence was captured at an emission wavelength of $300 \mathrm{~nm}$ and an excitation wavelength of $535 \mathrm{~nm}$.

The content of $\mathrm{H}_{2} \mathrm{O}_{2}$ in the rice roots was indicated by the intensity of green fluorescence after staining with $2^{\prime}, 7^{\prime}-$ dichlorodihydrofluorescein diacetate. The 1 -cm rice root tips were collected and stained in 50- $\mathrm{MM} 2^{\prime}, 7^{\prime}$ -

dichlorodihydrofluorescein diacetate for $24 \mathrm{~h}$ at room temperature, following which the extra dye was washed off using HEPES-KOH buffer (20 mM, pH 7.8). The fluorescent image was captured by a fluorescence microscope (LEICA DM2500) (Chen et al., 2013b).

\section{Real-time PCR}

The total RNA was extracted by TRIzol reagent (Invitrogen, Germany) according to the instructions and reverse transcribed to cDNA immediately. The reaction mixture for real time (RT) PCR was according to Zhu et al. (2016). The 
sequences of selected genes and reference gene primers are displayed in Table S1. The relative expression of selected genes was calculated according to a previous study (Livak and Schmittgen, 2001).

\section{Western blot}

The total protein was extracted, and the Bradford method was used to determine the protein content (Bradford, 1976). The SDS-PAGE method was used to separate proteins (20 $\mu \mathrm{g}$ for each sample) and transfer them to a $0.45 \mu \mathrm{m}$ polyvinylidene difluoride (PVDF) membrane immediately (Laemmli, 1970). The protein blot was probed with a primary antibody of ascorbate peroxidase (APX; AS08 368, Agrisera, Sweden), catalase (CAT; AS09 501), ATP synthase (AS08 370, Agrisera, Sweden), and monoclonal anti-actin (plant) antibody produced in mice (A0480, Sigma, USA) at dilutions of $1: 1000,1: 10000$, and 1:1000 after resting on the PVDF membrane for $2 \mathrm{~h}$ at $25^{\circ} \mathrm{C}$. We then probed the secondary antibody (HRP-labeled Goat Anti-Rabbit IgG $(\mathrm{H}+\mathrm{L})$ and HRP-labeled Goat Anti-Rat IgG $(\mathrm{H}+\mathrm{L})$ at a 1:1000 dilution for $2 \mathrm{~h}$ at $25^{\circ} \mathrm{C}$. The enhanced chemiluminescence (Pierce, Waltham, WA, USA) was used to obtain blot images, and the Quantity One software (Bio-Rad, Hercules, CA, USA) was used to analyze the band intensities.

\section{Statistical analysis}

All experiments in the present study were performed with three independent biological replicates. A one-way ANOVA was used to analyze the data, and a post hoc Tukey's test was used to compare the mean values at $P<0.05$ (SPSS 13.0). The $\mathrm{R}$ program (version 3.0.0; R Development Core Team) with the vegan package was used to perform multivariate analyses.

\section{Results}

\section{Effect of $\mathrm{H}_{2} \mathrm{~S}$ on rice growth under Al toxicity conditions}

The Al treatment significantly inhibited the elongation of the rice roots, amplified the total Al content in the rice roots and shoots, and increased the Al concentration in the rice apoplast and cytoplasm (Fig. 1). However, pretreatment with NaHS $\left(\mathrm{H}_{2} \mathrm{~S}\right.$ donor) significantly reversed the inhibition of root growth induced by Al toxicity and also decreased the total Al content and the Al concentration in the rice apoplast and cytoplasm under Al conditions (Fig. 1), indicating that $\mathrm{H}_{2} \mathrm{~S}$ is involved in alleviating Al toxicity in rice.

\section{Identification of DEGs by transcriptome sequencing}

The results of the clean reads, Pearson's correlation coefficient analysis, principal components analysis (PCA), and hierarchical clustering analysis for each sample are provided in the supplementary material (Table S1-2, Fig. S2-3). The DEGs were obtained according to $P<0.05$ and $\log _{2} F C>1$ by the edgeR software, and the results showed that in the group of $\mathrm{Al} / \mathrm{CK}$, there were 529 upregulated genes and 282 downregulated genes. In the group of S/CK, there were 190 upregulated genes and 202 downregulated genes. In the group of Al+S/Al, there were 260 upregulated genes and 276 downregulated genes (Fig. 2A).

The Venn diagram indicated that 385, 584, and 236 genes were only differentially expressed in the Al-S/Al, Al/CK, and S/CK groups, 27 DEGs co-existed in the Al-S/Al and S/CK groups, 98 DEGs co-existed in the Al/CK and Al-S/Al groups, 103 DEGs co-existed in the Al/CK and S/CK groups, and 26 DEGs co-existed in three groups (Fig. 2B).

The GO classification in the biological process indicated that the top three DEGs belonged to metabolic process, cellular process, and single-organism process. For the molecular function category, the top three genes belonged to binding fractions, catalytic activity, and nucleic acid binding transcription factor activity. In addition, cellular component analysis found that the locations of the top three genes were the membrane, cell, and cell part (Fig. 3A). 
The KEGG analysis also showed that most of the DEGs were involved in metabolism, such as carbohydrate metabolism, energy metabolism, and biosynthesis of other secondary metabolism. The other pathways included genetic information processing, environmental information processing, and cellular processes (Fig. 3B).

\section{$\mathrm{H}_{2} \mathrm{~S}$ improved energy production and the antioxidant system in rice}

The Al treatment significantly decreased the sucrose content, ATP content, and the protein abundance of ATP synthase in the rice roots compared with CK. However, pretreatment with NaHS significantly reversed these negative effects induced by Al toxicity (Fig. 4).

The Al treatment also affected the antioxidant system in the rice roots. GSH and AsA, which are involved in alleviating peroxidation damage, were induced by Al toxicity and further increased after applying NaHS to the rice roots. In addition, the $\mathrm{O}_{2}{ }^{--}$and $\mathrm{H}_{2} \mathrm{O}_{2}$ content, indicated by the intensity of the red and green fluorescence, significantly increased under $\mathrm{Al}$ toxicity conditions and decreased following pretreatment with NaHS under Al toxicity conditions (Fig. 4). The protein abundance of APXs (SAPX and PAPX) decreased under Al toxicity conditions and increased following pretreatment with $\mathrm{NaHS}$ under Al toxicity (Fig. 4), suggesting that $\mathrm{H}_{2} \mathrm{~S}$ reduced the peroxidation stress induced by Al toxicity.

\section{$\mathrm{H}_{2} \mathrm{~S}$ inhibited ethylene emission to reduce cell wall Al deposition in rice}

Ethylene emissions increased under Al toxicity conditions and decreased after pretreatment with NaHS under Al toxicity (Fig. 5). A single application of the ethylene synthesis inhibitor AVG alone or in combination with NaHS significantly improved rice root growth, decreased the Al content in the rice roots and cell walls, and decreased the pectin content and pectin methylation degree; however, the application of the ethylene synthesis precursor ACC had an opposite tendency and even negated the positive role of NaHS in alleviating Al toxicity (Fig. 5).

In addition, the content of IAA and $B L$ in the rice roots decreased under $\mathrm{Al}$ toxicity conditions and increased after pretreatment with NaHS under Al toxicity, and the exogenous application of IAA and BL both decreased the rice root AI content (Fig. S4).

\section{Discussion}

\section{$\mathrm{H}_{2} \mathrm{~S}$ regulated material metabolism to alleviate Al toxicity}

The Al stress significantly affected material metabolism in the plants, and exogenously applied signaling material alleviated the Al toxicity by regulating plant material metabolism. In our study, pretreatment with the $\mathrm{H}_{2} \mathrm{~S}$ donor $\mathrm{NaHS}$ induced a series of changes to material metabolism genes, including carbon metabolism (Nos. 1, 2), protein metabolism (Nos. 3, 4, 5), lipid metabolism (Nos. 6, 7, 8, 9, 10), energy production (Nos. 26, 27), and secondary metabolism (Nos. 56, $57,58)$ (Table 1). Sucrose is responsible for energy supply and also acts as a signaling molecule in plants (Kühn and Grof, 2010). Producing enough sucrose and transporting sucrose to the right site is pivotal for plants to resist stress. A previous study demonstrated that sucrose transporters are involved in orchestrating sucrose allocation both intracellularly and at the whole plant level (Kühn and Grof 2010). In our study, the gene expression of the sucrose transporter (No. 2, Table 1) significantly decreased in the Al/CK set and increased in the Al+S/Al set, and this was accompanied by an increased sucrose content when the rice roots were pretreated with NaHS under Al toxicity conditions (Fig. 4B), suggesting that $\mathrm{H}_{2} \mathrm{~S}$ not only stimulates the production of sucrose but is also involved in regulating sucrose allocation to resist Al toxicity. ATP is the direct energy source for plant development, and most of the ATP in cells is produced in the mitochondria. Thus, maintaining the integrity and normal functioning of the mitochondria is important for producing enough energy in organisms (Harris and Das 1991). The GCN5-like protein 1 is responsible for the regulation of mitochondrial biogenesis and mitophagy (Scott et al. 2014). Kinesin superfamily proteins play an important 
role in mitochondrial and lysosomal dispersion. In our study, the expression of GCN5-like 1 domain containing protein (No. 26) and kinesin heavy chain (No. 27) genes significantly increased in the Al+S/Al set (Table 1), and it was also accompanied by increased ATP content and ATP synthase abundance in the rice roots once pretreated with NaHS under Al toxicity conditions (Figs. $4 \mathrm{~A}$ and I). This indicated that $\mathrm{H}_{2} \mathrm{~S}$ maintained sufficient ATP in the rice roots to help the rice resist Al toxicity.

F-box proteins are responsible for catalyzing protein ubiquitination and maintaining the balance between protein synthesis and degradation (Boycheva et al., 2015); therefore, the increased expression of cyclin-like F-box domain containing protein (No. 3) in the Al+S/Al set in our study (Table 1) indicated that $\mathrm{H}_{2}$ S regulated the protein synthesis under Al toxicity. Previous studies have demonstrated that the carboxyl in the cell wall and phosphate in the plasma membrane are the main sites that bind with $\mathrm{Al}^{3+}$ and aggravate $\mathrm{Al}$ toxicity in plants (Kochian et al., 2005). Non-specific lipid transfer proteins (nsLTPs) are located in the plant cell wall and respond to the transfer of phospholipids (Thoma et al., 1993; Zhang et al., 2019). 3-Ketoacyl-coenzyme A synthase (KCS) and $\beta$-ketoacyl-CoA synthase are involved in the synthesis of long chain fatty acids in plants, including sphingolipids and phospholipids (Kim et al., 2013b; Li et al., 2018). In the present study, the expression of nonspecific lipid-transfer protein 3 (Nos. 6-8), 3-ketoacyl-CoA synthase (No. 9), and beta-ketoacyl-CoA synthase (No. 10) significantly decreased in the Al+S/Al set (Table 1), indicating that $\mathrm{H}_{2} \mathrm{~S}$ might decrease the transfer and synthesis of phospholipids to inhibit Al accumulation and then alleviate Al toxicity in rice.

Flavonoids are secondary metabolites present in higher plants that play an important role in plant development and abiotic and biotic stress resistance (Mo et al., 1992; Stapleton and Walbot, 1994). Flavanone 3-hydroxylase catalyzes the formation of dihydroflavonols from flavanones, therefore providing precursors for many classes of flavonoid compounds (Pelletier and Shirley, 1996). MYBL2 is a negative regulator of flavonoid synthesis in Arabidopsis (Dubos et al., 2008), and OsWD40 family genes are co-expressed with MYB factors to initiate their diverse functions (Ouyang et al., 2012). In the present study, the expression of flavanone 3-hydroxylase 3 (No. 56) significantly increased; however, the expression of both MYBL2 (No. 57) and OsWD40-77 (No. 58) significantly decreased in the Al+S/Al set (Table 1), indicating that $\mathrm{H}_{2} \mathrm{~S}$ increased flavonoid synthesis to improve rice Al toxicity resistance.

\section{$\mathrm{H}_{2} \mathrm{~S}$ alleviates Al toxicity by reducing cell wall deposition}

Cell walls are the main site for Al deposition, and the removal of Al from the cell wall significantly improves plant growth. Pectin and hemicellulose are the major Al deposition sites in plant cell walls; for example, about $76 \%$ of $\mathrm{Al}$ in the tobacco cell wall is in the pectin (Chang et al., 1999) and most of cell wall Al in Arabidopsis roots is in the hemicellulose fraction (Yang et al., 2011). In our study, five DEGs (Nos. 11-15) associated with polysaccharide synthesis and construction modification were identified (Table 1). Among them, pectinesterase inhibitor is involved in blocking the process of demethylation in plants and thus reduces the negative charges in pectin in plants to decrease the binding of $\mathrm{Al}^{3+}(\mathrm{Van}$ Beusichem et al., 1988). Glycoside hydrolase family proteins are involved in hemicellulose breakdown (Langston et al., 2011). Xylanase is responsible for catalyzing the degradation of the hemicellulose main composition material xylan and the glycoside hydrolase family 18-member xylanase inhibitor protein I (XIP-I), which are responsible for inhibiting the activity of xylanase (Anne et al., 2005; Jensen et al., 2018). Arabinogalactan-proteins (AGPs) participate in cell wall polysaccharide synthesis; for example, the mutant of agp30 in Arabidopsis exhibited significantly decreased pectin content (Hengel and Roberts, 2003). In the present study, the expression of the pectinesterase inhibitor domain containing protein (No. 11) and glycoside hydrolase (No. 12) increased, while the expression of glycoside hydrolase family 18 (No. 13) and arabinogalactan protein 1 and 2 (Nos. 14, 15) decreased, following the application of NaHS under Al toxicity conditions (Table 1), which indicated that $\mathrm{H}_{2} \mathrm{~S}$ reduced the cell wall polysaccharide content to reduce cell wall $\mathrm{Al}$ deposition. Furthermore, we also found that two wall-associated kinase (WAK) genes (Nos. 18, 19), which are related to cell growth (Kim and Guerinot, 2007; Walker and Connolly, 2008), significantly increased after the application of NaHS 
under Al toxicity conditions (Table 1 ). This implies that $\mathrm{H}_{2} \mathrm{~S}$ improved the expression of the WAK gene to improve rice root growth under Al toxicity conditions.

\section{$\mathrm{H}_{2} \mathrm{~S}$ alleviates the peroxidation damage induced by Al toxicity}

Al toxicity significantly increased the $\mathrm{H}_{2} \mathrm{O}_{2}$ and $\mathrm{O}_{2}{ }^{--}$content in the rice roots (Figs. $4 \mathrm{E}-\mathrm{G}$ ), suggesting that Al induced peroxidation damage in rice. To remove the excess oxidizing substances, the content of the most important antioxidants in rice roots, namely GSH and AsA (Jones, 2002), both significantly increased after NaHS application (Figs 4 C and D). In addition, enzymes belonging to the antioxidant system were also identified in the present study. Among them, germins and germin-like proteins (GLPs) possess the enzyme functions of superoxide dismutase (SOD) to produce $\mathrm{H}_{2} \mathrm{O}_{2}$ and play a pivotal role in plant development and defense, such as by improving blast disease resistance in rice (Manosalva et al., 2009). Thioredoxins are major cellular protein disulfide reductases that play a role in $\mathrm{H}_{2} \mathrm{O}_{2}$ removal (Chae et al., 1999). Peroxisomes are simple organelles present in most organisms and play an important role in ROS metabolism (Corpas et al., 2017). Ascorbate oxidase (AO) is responsible for converting ascorbate to monodehydroascorbate and reducing oxygen to water at the same time (Stevens et al., 2017). In our study, the expression of germin-like proteins (Nos. 28-34), thioredoxin domain 2 containing protein (No. 35), peroxisomal biogenesis factor 19 (No. 36), and L-ascorbate oxidase precursor (No. 39) all increased in the Al+S/Al set (Table1). However, the expression of benzothiadiazole-induced protein (No. 37), which participates in inhibiting CAT and APX to increase $\mathrm{H}_{2} \mathrm{O}_{2}$ content in plants (Iriti et al., 2003), decreased (Table 1). In addition, although the protein content of CAT did not change before or after the application of NaHS, the protein contents of SAPX and tAPX both significantly increased (Fig. $4 \mathrm{I}$ ), further confirming that $\mathrm{H}_{2} \mathrm{~S}$ alleviates peroxidation damage by reducing peroxides.

\section{The phytohormones involved in $\mathrm{H}_{2} \mathrm{~S}$ alleviation of Al toxicity}

In addition, $\mathrm{H}_{2} \mathrm{~S}$ often interacts with other signaling molecules to regulate the plant response to various stresses (Jin and Pei, 2015), such as nitric oxide, salicylic acid, abscisic acid, and $\mathrm{Ca}^{2+}$ (Fang et al., 2014; Li et al., 2015; Peng et al., 2016; Jin et al., 2013; Wang et al., 2018). In our study, we also identified some genes involved in the regulation of phytohormone synthesis, metabolism, and signal transduction. Ethylene emissions are induced by Al toxicity and aggravate Al toxicity in Lotus japonicus L. and Arabidopsis (Sun et al., 2007; Sun et al., 2010). The ACC oxidase is responsible for the final step of ethylene production, which catalyzes 1-aminocyclopropane carboxylic acid (ACC) to ethylene (Kende, 1993). GDSL lipase-like 1 regulates systemic resistance and is required for ethylene signaling in plants (Kwon et al., 2009). In the present study, ethylene emissions and the related gene ACC oxidase (No. 23) decreased in the Al+S/Al set and therefore decreased the expression of lipase and GDSL domain-containing protein (Nos. 24, 25) (Table 1). In addition, a previous study found that ethylene stimulates pectin synthesis in rice, and thus there is a hypothesis that $\mathrm{H}_{2} \mathrm{~S}$ decreases ethylene synthesis to reduce the pectin content, which then reduces the Al content in rice roots. In the present study, the application of the ethylene synthesis inhibitor AVG alone or together with NaHS significantly increased rice root growth, decreased cell wall $\mathrm{Al}$ and total $\mathrm{Al}$ content in the rice roots, and inhibited the degree of pectin synthesis and demethylation esterification, whereas the ethylene synthesis precursor ACC had an opposite tendency and even negated the positive role of $\mathrm{H}_{2} \mathrm{~S}$ in alleviating Al toxicity once applied with $\mathrm{NaHS}$ (Fig. 5).

Furthermore, the expression of some genes related to IAA (Nos. 21, 40-42) and BL (No. 43) also increased after pretreatment with $\mathrm{H}_{2} \mathrm{~S}$ under $\mathrm{Al}$ toxicity conditions, including tryptophan decarboxylase, which is responsible for catalyzing the first step of IAA synthesis that transfers tryptophan to tryptamine (Majerus et al. 2009) (Table 1). The small auxin-up RNA (SAUR) genes are early auxin-responsive genes that play a role in auxin-mediated cell elongation (Longnecker and Welch, 1990). Brassinosteroid insensitive 1 (BRI1)-Associated Kinase I (BAK1) is one of the key components in the brassinosteroid signal transduction pathway and is involved in regulating rice growth and development (Huang et al., 2012; Lei et al., 2014). In addition, the content of IAA and BL both increased in the rice roots 
following pretreatment with NaHS under Al toxicity conditions and was accompanied by a decrease in the Al content in the rice root tips after exogenous application of IAA and BL under Al toxicity (Fig. S4). This further confirmed that $\mathrm{H}_{2} \mathrm{~S}$ cross-talks with IAA and $B L$ to alleviate $\mathrm{Al}$ toxicity in rice.

\section{$\mathrm{H}_{2} \mathrm{~S}$ regulated transcriptional and translational pathways to alleviate Al toxicity}

Transcriptional and translational pathways that control the expression of stress-responsive genes are pivotal for the plant response to various stresses (Romheld and Marschner, 1986). Eukaryotic translation initiation factor 2 is involved in the initiation of polypeptide chain synthesis (Bienfait et al., 1985). Toll-interleukin-1 receptor domain (TIR) is associated with the response of growth factors in plants (Guerinot and Yi, 1994; Mori, 1999). Apetala2 (AP2) transcription factor genes belong to the ethylene response factor (ERF) subfamily (Jofuku et al., 1994; Ohme-Takagi and Shinshi, 1995). AP2/ERF family transcription factors, including the subfamily of dehydration-responsive element, play an important role in seed development (Boutilier et al., 2002) and response to environmental stress (Zhu et al., 2010). In the present study, the expression of eukaryotic translation initiation factor 2 (No. 48), toll-interleukin receptor domain containing protein (No. 49), AP2/ERF transcription factor (Nos. 50, 51), dehydration-responsive element (Nos. 52, 53), ethylene-responsive transcription factor 2 (No. 54), and ERF domain containing protein (No. 55) all significantly increased in the Al+S/Al set (Table 1), indicating that $\mathrm{H}_{2} \mathrm{~S}$ stimulates ethylene response transcription factors to increase Al resistance ability.

\section{$\mathrm{H}_{2} \mathrm{~S}$ inhibited the transport of Al from the roots to the shoots by mediating genes related to ion uptake and transport}

Heavy metal-associated (HMA) proteins are involved in heavy metal uptake and internal transportation in plants; for example, OsHMA2 localizes to root pericycle cells and is associated with the transportation of heavy metal $\mathrm{Cd}^{2+}$ from the roots to shoots (Yamaji et al., 2013). In the present study, the expression of heavy-metal-associated domain-containing protein (No. 59) significantly decreased in the Al+S/Al set. This was concurrent with a decreasing shoot-root-Al-content ratio (Fig. 1E), indicating that $\mathrm{H}_{2} \mathrm{~S}$ not only decreased the Al uptake but also inhibited its transportation from the roots to the shoots.

\section{Conclusion}

As show in Fig. 9, $\mathrm{H}_{2} \mathrm{~S}$ improved energy production, reduced peroxidation damage, and decreased Al binding in the cell membrane to alleviate Al toxicity. In addition, $\mathrm{H}_{2} \mathrm{~S}$ inhibited ethylene emissions to reduce pectin content and improved the pectin methylation degree to decrease cell wall Al deposition. The phytohormones IAA and BL were also found to be involved in the alleviation of Al toxicity by $\mathrm{H}_{2} \mathrm{~S}$. Additionally, $\mathrm{H}_{2} \mathrm{~S}$ also regulated secondary metabolism (such as flavonoids), transcriptional and translational pathways, or inhibited the transportation of Al from the roots to the shoots to alleviate Al toxicity in rice

\section{Abbreviations}

$\mathrm{H}_{2} \mathrm{~S}$ : Hydrogen sulfide;

\section{Al: Aluminum;}

ROS: reactive oxygen species;

DEGs: differentially expressed genes;

GO: Gene Ontology;

KEGG: Kyoto Encyclopedia of Genes and Genomes; 
IAA: Indole-3-acetic acid;

BL: Brassinolide;

PVDF: polyvinylidene difluoride;

PCA: principal components analysis;

ACC: 1-aminocyclopropane carboxylic acid

\section{Declarations}

\section{Ethical Approval and Consent to participate}

Not applicable.

\section{Consent for publication}

All authors agreed to the publication.

\section{Availability of supporting data}

The raw data supporting the conclusions of this manuscript will be made available by the authors, without undue reservation, to any qualified researcher.

\section{Competing interests}

The authors declare that they have no competing interests.

\section{Funding}

This work was funded by the National Natural Science Foundation of China (No. 31901452), the Zhejiang Provincial Natural Science Foundation of China (No. LQ19C020007, LY18C020005).

\section{Authors' contributions}

C.Q.Z., W.J.H, Q.Q.W., and H.Z. performed research; C.Q.Z., X.C.C, L.F.Z. and Y.L.K. analyzed data, C.Q.Z. and X.J.X. wrote the draft; J.L., Q.Y.J. and J.H.Z. revised the article; C.Q.Z., X.J.X., and J.H.Z. designed the research.

\section{Acknowledgements}

This work was funded by the National Natural Science Foundation of China (No. 31901452), the Zhejiang Provincial Natural Science Foundation of China (No. LQ19C020007, LY18C020005).

\section{References}

1. Abdullahi BA, Gu XG, Gan QL, Yang YH (2002) Brassinolide amelioration of aluminum toxicity in mungbean seedling growth. J Plant Nutr 26:1725-1734. DOI:10.1081/PLN-120023278

2. Anne D, Richard H, Alain R, Ruth F, Bernard H, Nathalie J (2005) Emergence of a subfamily of xylanase inhibitors within glycoside hydrolase family 18. Febs Journal 272:1745-1755. DOI:10.1111/j.1742-4658.2005.04606.x

3. Bajguz A (2011) Suppression of chlorella vulgaris growth by cadmium, lead, and copper stress and its restoration by endogenous brassinolide. Arch Environ Contam Toxicol 60:406-416. DOI:10.1007/s00244-010-9551-0 
4. Banerjee A, Tripathi DK, Roychoudhury A (2018) Hydrogen sulphide trapeze: Environmental stress amelioration and phytohormone crosstalk. Plant physiology biochemistry 132:46-53. DOI:10.1016/j.plaphy.2018.08.028

5. Bienfait HF, van den Briel W, Mesland-Mul NT (1985) Free space iron pools in roots. Plant Physiol 78:596-600. DOI:10.1104/pp.78.3.596

6. Boutilier K, Offringa R, Sharma VK, Kieft H, Ouellet T, Zhang L, Hattori J, Liu C-M, van Lammeren AA, Miki BL (2002) Ectopic expression of BABY BOOM triggers a conversion from vegetative to embryonic growth. Plant Cell 14:17371749. DOI:10.1005/Tpc.001941

7. Boycheva I, Vassileva V, Revalska M, Zehirov G, lantcheva A (2015) Cyclin-like F-box protein plays a role in growth and development of the three model species Medicago truncatula, Lotus japonicus, and Arabidopsis thaliana. Research Reports in Biology 6:117. DOI:10.2147/rrb.s84753

8. Bradford M (1976) A rapid and sensitive method for the quantitation of microgram quantities of protein utilizing the principles of protein-dye binding. Anal Biochem 71:248-254. DOI:10.1016/0003-2697(76)90527-3

9. Chae HZ, Kang SW, Rhee SG (1999) Isoforms of mammalian peroxiredoxin that reduce peroxides in presence of thioredoxin. In: Methods in enzymology. Elsevier, pp 219-226. DOI:10.1016/S0076-6879(99)00128-7

10. Chang YC, Yamamoto Y, Matsumoto H (1999) Accumulation of aluminium in the cell wall pectin in cultured tobacco (Nicotiana tabacum L.) cells treated with a combination of aluminium and iron. Plant Cell Environment 22:10091017. DOI:10.1046/j.1365-3040.1999.00467.x

11. Chen J, Wang W-H, Wu F-H, You C-Y, Liu T-W, Dong X-J, He J-X, Zheng H-L (2013a) Hydrogen sulfide alleviates aluminum toxicity in barley seedlings. Plant soil 362:301-318. DOI:10.1007/s11104-012-1275-7

12. Chen YH, Chao YY, Yun YH, Kao CH (2013b) Heme oxygenase is involved in $\mathrm{H} 2 \mathrm{O} 2$-induced lateral root formation in apocynin-treated rice. Plant Cell Rep 32:219-226. DOI:10.1007/s00299-012-1356-3

13. Corpas FJ, Barroso JB, Palma JM, Rodriguez-Ruiz M (2017) Plant peroxisomes: a nitro-oxidative cocktail. Redox Biol 11:535-542. DOI:10.1016/j.redox.2016.12.033

14. Dawood M, Cao F, Jahangir MM, Zhang G, Wu F (2012) Alleviation of aluminum toxicity by hydrogen sulfide is related to elevated ATPase, and suppressed aluminum uptake and oxidative stress in barley. Journal of Hazardous Materials s 209-210, 121-128. DOI:10.1016/j.jhazmat.2011.12.076

15. Dubos C, Gourrierec JL, Baudry A, Huep G, Lepiniec L (2008) MYBL2 is a new regulator of flavonoid biosynthesis in Arabidopsis thaliana. Plant J 55:940-953. DOI:10.1111/j.1365-313X.2008.03564.x

16. Fang H, Jing T, Liu Z, Zhang L, Jin Z, Pei Y (2014) Hydrogen sulfide interacts with calcium signaling to enhance the chromium tolerance in Setaria italica. Cell Calcium 56:472-481. DOI:10.1016/j.ceca.2014.10.004

17. Filipovic MR (2015) Persulfidation (S-sulfhydration) and H 2 S, Chemistry, biochemistry and pharmacology of hydrogen sulfide. Springer, pp 29-59. DOI:10.1007/978-3-319-18144-8_2

18. Guan MY, Zhang HH, Pan W, Jin CW, Lin XY (2018) Sulfide alleviates cadmium toxicity in Arabidopsis plants by altering the chemical form and the subcellular distribution of cadmium. Sci Total Environ 627:663-670. DOI:10.1016/j.scitotenv.2018.01.245

19. Guerinot ML, Yi Y (1994) Iron: Nutritious, Noxious, and Not Readily Available. Plant Physiol 104:815-820. Doi:10.1104/pp.104.3.815

20. He HY, He LF, Gu MH, Li XF (2012) Nitric oxide improves aluminum tolerance by regulating hormonal equilibrium in the root apices of rye and wheat. Plant Sci 183:123-130. DOI:10.1016/j.plantsci.2011.07.012

21. Hengel AJV, Roberts K (2003) AtAGP30, an arabinogalactan-protein in the cell walls of the primary root, plays a role in root regeneration and seed germination. Plant J 36:256-270. DOI:10.1046/j.1365-313X.2003.01874.x

22. Huang SS, Chen J, Dong XJ, Patton J, Pei ZM, Zheng HL (2012) Calcium and calcium receptor CAS promote Arabidopsis thaliana de-etiolation. Physiol Plant 144:73-82. DOI:10.1111/j.1399-3054.2011.01523.x

Page $11 / 24$ 
23. Iriti M, Rabotti G, De Ascensao A, Faoro F (2003) Benzothiadiazole-Induced Resistance Modulates Ozone Tolerance. J Agric Food Chem 51:4308-4314. DOI:10.1021/jf034308w

24. Jensen JK, Busse-Wicher M, Poulsen CP, Fangel JU, Smith PJ, Yang JY, Pe?a M-J, Dinesen MH, Martens HJ, Melkonian M (2018) Identification of an algal xylan synthase indicates that there is functional orthology between algal and plant cell wall biosynthesis. New Phytol 218. DOI:10.1111/nph.15050

25. Jofuku KD, Boer BGWd, Montagu MV, Okamuro JK (1994) Control of Arabidopsis Flower and Seed Development by the Homeotic Gene APETALA2. Plant Cell 6:1211-1225. DOI:10.2307/3869820

26. Jones DP (2002) Redox potential of GSH/GSSG couple: assay and biological significance. Methods Enzymol 348:93-112. DOI:10.1016/S0076-6879(02)48630-2

27. Jin ZP, Pei YX (2015) Physiological implications of hydrogen sulfide in plants: pleasant exploration behind its unpleasant dour. Oxidative Medicine and Cellular Longevity 2015, 397502. DOI: 10.1155/2015/397502

28. Jin Z, Luo XS, Tian Y, Fang B, Li H, Pei H, Y (2013) Hydrogen sulfide interacting with abscisic acid in stomatal regulation responses to drought stress in Arabidopsis. Plant Physiol Biochem 62:41-46.

DOI:10.1016/j.plaphy.2012.10.017

29. Kühn C, Grof CP (2010) Sucrose transporters of higher plants. Curr Opin Plant Biol 13:287-297.

DOI:10.1016/j.pbi.2010.02.001

30. Köpnick C, Grübe M, Stock J, Senula A, Mock HP, Nagel M (2018) Changes of soluble sugars and ATP content during DMSO droplet freezing and PVS3 droplet vitrification of potato shoot tips. Cryobiology 85.

DOI:10.1016/j.cryobiol.2018.09.005

31. Kende H (1993) Ethylene biosynthesis. Annu Rev Plant Biol 44:283-307

32. Kim D, Pertea G, Trapnell C, Pimentel H, Kelley R, Salzberg SL (2013a) TopHat2: accurate alignment of transcriptomes in the presence of insertions, deletions and gene fusions. Genome biology 14:R36. DOI:10.1186/gb2013-14-4-r36

33. Kim J, Jin HJ, Lee SB, Go YS, Kim HJ, Cahoon R, Cahoon EB, Markham JE, Mi CS (2013b) Arabidopsis 3-ketoacylCoA synthase 9 is involved in the synthesis of tetracosanoic acids as precursors of cuticular waxes, suberins, sphingolipids, and phospholipids. PLANT PHYSIOLOGY 162:567-580. DOI:10.1104/pp.112.210450

34. Kim SA, Guerinot ML (2007) Mining iron: Iron uptake and transport in plants. Febs Letters 581:2273-2280. DOI:10.1016/j.febslet.2007.04.043

35. Kochian LV, Pineros MA, Hoekenga OA (2005) The physiology, genetics and molecular biology of plant aluminum resistance and toxicity, Root Physiology: from Gene to Function. Springer, pp 175-195. DOI:10.1007/s11104-0041158-7

36. Kwon SJ, Jin HC, Lee S, Nam MH, Chung JH, Kwon SI, Ryu CM, Park OK (2009) GDSL lipase-like 1 regulates systemic resistance associated with ethylene signaling in Arabidopsis. Plant J 58:235-245. DOI:10.1111/j.1365313X.2008.03772.x

37. Langmead B, Salzberg SL (2012) Fast gapped-read alignment with Bowtie 2. Nature methods 9:357. DOI:10.1038/nmeth.1923

38. Langston JA, Shaghasi T, Abbate E, Xu F, Vlasenko E, Sweeney MD (2011) Oxidoreductive cellulose depolymerization by the enzymes cellobiose dehydrogenase and glycoside hydrolase 61. Appl Environ Microbiol 77:7007-7015.

DOI:10.1128/AEM.05815-11

39. Lei GJ, Zhu XF, Wang ZW, Dong F, Dong NY, Zheng SJ (2014) Abscisic acid alleviates iron deficiency by promoting root iron reutilization and transport from root to shoot in Arabidopsis. Plant Cell Environ 37:852-863.

DOI:10.1111/pce.12203

Page 12/24 
40. Li B, Dewey CN (2011) RSEM: accurate transcript quantification from RNA-Seq data with or without a reference genome. BMC Bioinform 12:323. DOI:10.1186/1471-2105-12-323

41. Li C, Haslam TM, Krüger A, Schneider LM, Mishina K, Samuels L, Yang H, Kunst L, Schaffrath U, Nawrath C (2018) The $\beta$-ketoacyl-CoA Synthase HvKCS1, Encoded By Cer-zh, Plays A Key Role In Synthesis Of Barley Leaf Wax And Germination Of Barley Powdery Mildew. Plant Cell Physiology 59:806-822. DOI:10.1093/pcp/pcy020

42. Li X, Li Y, Qu M, Xiao H, Feng Y, Liu J, Wu L, Yu M (2016) Cell Wall Pectin and its Methyl-esterification in Transition Zone Determine Al Resistance in Cultivars of Pea (Pisum sativum). Front Plant Sci 7:39.

DOI:10.3389/fpls.2016.00039

43. Li YS, Du M, Zhang QY, Wang GH, Liu XB (2012a) Greater differences exist in seed protein, oil, total soluble sugar and sucrose content of vegetable soybean genotypes [Glycine max (L.) Merrill] in Northeast China. Australian Journal of Crop ence 6:1681-1686. DOI:10.13140/2.1.2841.2163

44. Li Z (2013) Hydrogen sulfide: a multifunctional gaseous molecule in plants. Russian journal of plant physiology 60:733-740. DOI:10.1134/S1021443713060058

45. Li ZG, Gong M, Xie H, Yang L, Li J (2012b) Hydrogen sulfide donor sodium hydrosulfide-induced heat tolerance in tobacco (Nicotiana tabacum L) suspension cultured cells and involvement of Ca2 + and calmodulin. Plant Sci 185186, 0-189. DOI:10.1016/j.plantsci.2011.10.006

46. Li ZG, Xie LR, Li XJ (2015) Hydrogen sulfide acts as a downstream signal molecule in salicylic acid-induced heat tolerance in maize (Zea mays L.) seedlings. J Plant Physiol 177:121-127. DOI:10.1016/j.jplph.2014.12.018

47. Liu X, Chen J, Wang GH, Wang WH, Zheng HL (2015) Hydrogen sulfide alleviates zinc toxicity by reducing zinc uptake and regulating genes expression of antioxidative enzymes and metallothioneins in roots of the cadmium/zinc hyperaccumulator Solanum nigrum L. Plant Soil 400:177-192. DOI:10.1007/s11104-015-2719-7

48. Livak KJ, Schmittgen TD (2001) Analysis of relative gene expression data using real-time quantitative PCR and the 2(-Delta Delta C(T)) Method. Methods 25:402-408. DOI:10.1006/meth.2001

49. Longnecker N, Welch RM (1990) Accumulation of Apoplastic Iron in Plant Roots A Factor in the Resistance of Soybeans to Iron-Deficiency Induced Chlorosis? Plant physiology 92, 17-22. DOI: 10.1104/pp.92.1.17

50. Manosalva PM, Davidson RM, Liu B, Zhu X, Hulbert SH, Leung H, Leach JE (2009) A germin-like protein gene family functions as a complex quantitative trait locus conferring broad-spectrum disease resistance in rice. Plant Physiol 149:286-296. DOI:10.1104/pp.108.128348

51. Majerus V, Bertin P, Lutts S (2009) Abscisic acid and oxidative stress implications in overall ferritin synthesis by African rice (Oryza glaberrima Steud.) seedlings exposed to short term iron toxicity. Plant soil 324:253.

DOI:10.1007/s11104-009-9952-x

52. Mo Y, Nagel C, Taylor LP (1992) Biochemical complementation of chalcone synthase mutants defines a role for flavonols in functional pollen. Proceedings of the National Academy of Sciences 89, 7213-7217. DOI:

10.1073/pnas.89.15.7213

53. Mori S (1999) Iron acquisition by plants. Curr Opin Plant Biol 2:250-253. DOI:10.1016/S1369-5266(99)80043-0

54. Muthusamy M, Hwang JE, Kim SH, Kim JA, Lee SI (2019) Elevated carbon dioxide signifcantly improves ascorbic acid content, antioxidative properties and restricted biomass production in cruciferous vegetable seedlings. Plant Biotechnology Reports. DOI:10.1007/s11816-019-00542-3

55. Ohme-Takagi S (1995) Ethylene-inducible DNA binding proteins that interact with an ethylene-responsive element. Plant Cell 7:173-182. DOI:10.1105/tpc.7.2.173

56. Ouyang Y, Huang X, Lu Z, Yao J (2012) Genomic survey, expression profile and co-expression network analysis ofOsWD40family in rice. Bmc Genomics 13:100-100. DOI:10.1186/1471-2164-13-100

Page $13 / 24$ 
57. Pelletier MK, Shirley BW (1996) Analysis of flavanone 3-hydroxylase in Arabidopsis seedlings (Coordinate regulation with chalcone synthase and chalcone isomerase). Plant physiology 111:339-345. DOI:10.1104/pp.111.1.339

58. Peng R, Bian Z, Zhou L, Cheng W, Hai N, Yang C, Yang T, Wang X, Wang C (2016) Hydrogen sulfide enhances nitric oxide-induced tolerance of hypoxia in maize (Zea mays L.). Plant Cell Rep 35:2325-2340. DOI:10.1007/s00299-0162037-4

59. Rizwan M, Mostofa MG, Ahmad MZ, Zhou Y, Adeel M, Mehmood S, Ahmad MA, Javed R, Imtiaz M, Aziz O (2019) Hydrogen sulfide enhances rice tolerance to nickel through the prevention of chloroplast damage and the improvement of nitrogen metabolism under excessive nickel. Plant Physiol Biochem 138:100-111. DOI:10.1016/j.plaphy.2019.02.023

60. Romheld V, Marschner H (1986) Mobilization of iron in the rhizosphere of different plant species. Advances in plant nutrition (USA)

61. Shen R, Ma J, Kyo M, Iwashita T (2002) Compartmentation of aluminium in leaves of an Al-accumulator, Fagopyrum esculentum Moench. Planta 215:394-398. DOI:10.1007/s00425-002-0763-z

62. Singh VP, Singh S, Kumar J, Prasad SM (2015) Hydrogen sulfide alleviates toxic effects of arsenate in pea seedlings through up-regulation of the ascorbate-glutathione cycle: Possible involvement of nitric oxide. J Plant Physiol 181:20-29. DOI:10.1016/j.jplph.2015.03.015

63. Sirko A, Błaszczyk A, Liszewska F (2004) Overproduction of SAT and/or OASTL in transgenic plants: a survey of effects. J Exp Bot 55:1881-1888. DOI:10.1093/jxb/erh151

64. Stapleton AE, Walbot V (1994) Flavonoids can protect maize DNA from the induction of ultraviolet radiation damage. Plant physiology 105:881-889. doi:10.1104/pp.105.3.881. DOI

65. Stevens R, Truffault V, Baldet P, Gautier H (2017) Ascorbate oxidase in plant growth, development, and stress tolerance, Ascorbic Acid in Plant Growth, Development and Stress Tolerance. Springer, pp 273-295. DOI: 10.1007/978-3-319-74057-7\$411

66. Sun N, Song T, Ma Z, Dong L, Feng Z, Xing Y, Liu J, Song J, Wang S, Cai H (2020) Overexpression of MsSiR enhances alkali tolerance in alfalfa (Medicago sativa L.) by increasing the glutathione content. Plant Physiol Biochem. DOI:10.1016/j.plaphy.2020.07.001

67. Sun P, Tian Q-Y, Zhao M-G, Dai X-Y, Huang J-H, Li L-H, Zhang W-H (2007) Aluminum-Induced Ethylene Production is Associated with Inhibition of Root Elongation in Lotus japonicus L. Plant Cell Physiol 48:1229-1235.

DOI:10.1093/pcp/pcm077

68. Sun P, Tian QY, Chen J, Zhang WH (2010) Aluminium-induced inhibition of root elongation in Arabidopsis is mediated by ethylene and auxin. J Exp Bot 61:347. DOI:10.1093/jxb/erp306

69. Tai CH, Cook PF (2000) O-acetylserine sulfhydrylase. Advances in enzymology and related areas of molecular biology 74, 185-234. DOI: 10.1002/9780470123201\$4ch5

70. Thoma S, Kaneko Y, Somerville C (1993) A non-specific lipid transfer protein from Arabidopsis is a cell wall protein. Plant Journal for Cell Molecular Biology 3:427-436. DOI:10.1046/j.1365-313X.1993.t01-25-00999.x

71. Trapnell C, Roberts A, Goff L, Pertea G, Kim D, Kelley DR, Pimentel H, Salzberg SL, Rinn JL, Pachter L (2012) Differential gene and transcript expression analysis of RNA-seq experiments with TopHat and Cufflinks. Nature protocols 7:562. DOI:10.1038/nprot.2012.016

72. Trapnell C, Williams BA, Pertea G, Mortazavi A, Kwan G, Van Baren MJ, Salzberg SL, Wold BJ, Pachter L (2010) Transcript assembly and quantification by RNA-Seq reveals unannotated transcripts and isoform switching during cell differentiation. Nature biotechnology 28:511. DOI:10.1038/nbt.1621

73. Van Beusichem ML, Kirkby EA, Baas R (1988) Influence of nitrate and ammonium nutrition on the uptake, assimilation, and distribution of nutrients in Ricinus communis. Plant Physiol 86:914-921. DOI:10.1104/pp.86.3.914 
74. Walker EL, Connolly EL (2008) Time to pump iron: iron-deficiency-signaling mechanisms of higher plants. Curr Opin Plant Biol 11:530-535. DOI:10.1016/j.pbi.2008.06.013

75. Wang Y, Li L, Cui W, Xu S, Shen W, Wang R (2012) Hydrogen sulfide enhances alfalfa (Medicago sativa) tolerance against salinity during seed germination by nitric oxide pathway. Plant soil 351:107-119. DOI:10.1007/s11104-0110936-2

76. Wang H, Ji F, Zhang Y, Hou J, Liu W, Huang J, Liang W (2019) Interactions between hydrogen sulfide and nitric oxide regulate two soybean citrate transporters during the alleviation of aluminium toxicity. Plant Cell Environ 42:23402356. DOI:10.1111/pce.13555

77. Xia J, Yamaji N, Kasai T, Ma JF (2010) Plasma membrane-localized transporter for aluminum in rice. Proc Natl Acad Sci USA 107:18381. DOI:10.1073/pnas.1004949107

78. Xia J, Yamaji N, Ma JF (2013) A plasma membrane-localized small peptide is involved in rice aluminum tolerance. Plant Journal for Cell Molecular Biology 76:345-355. DOI:10.1111/tpj.12296

79. Yamaji N, Xia J, Mitani-Ueno N, Yokosho K, Feng MJ (2013) Preferential delivery of zinc to developing tissues in rice is mediated by P-type heavy metal ATPase OsHMA2. Plant Physiol 162:927-939. DOI:10.1104/pp.113.216564

80. Yamasaki H, Cohen MF (2016) Biological consilience of hydrogen sulfide and nitric oxide in plants: Gases of primordial earth linking plant, microbial and animal physiologies. Nitric Oxide 56:91-100.

DOI:10.1016/j.niox.2016.04.002

81. Yang H, Pan R, Wang J, Zheng LZ, Li ZJ, Guo QB, Wang CL. Modulation of the gut microbiota and liver transcriptome by red yeast rice and monascus pigment fermented by purple monascus SHM1105 in rats fed with a high-fat diet. Front Pharmacol, 2021, 11. DOI:10.3389/fphar.2020.599760

82. Yokosho K, Yamaji N, Ma JF (2014) Global Transcriptome Analysis of Al-induced Genes in an Al-accumulating Species, Common Buckwheat (Fagopyrum esculentum Moench). Plant and Cell Physiology, pcu135. DOI: 10.1093/pcp/pcu135

83. Yu Y, Jin C, Sun C, Wang J, Ye Y, Zhou W, Lu L, Lin X (2016) Inhibition of ethylene production by putrescine alleviates aluminium-induced root inhibition in wheat plants. Sci Rep 6:18888. DOI:10.1038/srep18888

84. Zhang H, Hu L-Y, Li P, Hu K-D, Jiang C-X, Luo J-P (2010a) Hydrogen sulfide alleviated chromium toxicity in wheat. Biol Plant 54:743-747. DOI:10.1007/s10535-010-0133-9

85. Zhang, H., Hu, L.Y., Hu, K.D., He, Y.D., Wang, S.H., Luo, J.P., 2008. Hydrogen Sulfide Promotes Wheat Seed Germination

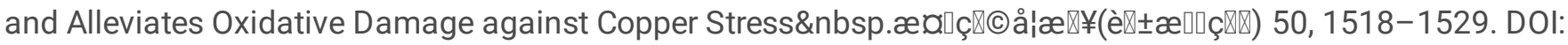
10.1111/j.1744-7909.2008.00769.x

86. Zhang H, Tan ZQ, Hu LY, Wang SH, Luo JP, Jones RL (2010b) Hydrogen Sulfide Alleviates Aluminum Toxicity in Germinating Wheat Seedlings. J Integr Plant Biol 52:556-567. DOI:10.4161/psb.5.8.12297

87. Zhang H, Wang M, Hu L, Wang S, Hu K, Bao L, Luo J (2010c) Hydrogen sulfide promotes wheat seed germination under osmotic stress. Russian journal of plant physiology 57:532-539. DOI:10.1134/S1021443710040114

88. Zhang M, Kim Y, Zong J, Lin H, Dievart A, Li H, Zhang D, Liang W (2019) Genome-wide analysis of the barley nonspecific lipid transfer protein gene family. The crop journal 7:65-76. DOI: CNKI:SUN:CROP.0.2019-01-009

89. Zhou W, Wei L, Xu J, Zhai Q, Jiang H, Chen R, Chen Q, Sun J, Chu J, Zhu L, Liu CM, Li C (2010) Arabidopsis tyrosylprotein sulfotransferase acts in the auxin/PLETHORA pathway in regulating postembryonic maintenance of the root stem cell niche. Plant Cell 22:3692-3709. DOI:10.1105/TPC.110.075721

90. Zhu C, Hu W, Cao X, Zhu L, Bai Z, Huang J, Liang Q, Jin Q, Zhang J (2020) Role of salicylic acid in alleviating the inhibition of root elongation by suppressing ethylene emission in rice under Al toxicity conditions. Plant Growth Regul 90:475-487. DOI:10.1007/s10725-019-00554-7

Page $15 / 24$ 
91. Zhu CQ, Zhang JH, Sun LM, Zhu LF, Abliz B, Hu WJ, Zhong C, Bai ZG, Sajid H, Cao XC, Jin QY (2018) Hydrogen sulfide alleviates aluminum toxicity via decreasing apoplast and symplast Al contents in rice. Front Plant Sci 9. DOI:10.3389/fpls.2018.00294

92. Zhu Q, Zhang J, Gao X, Tong J, Xiao L, Li W, Zhang H (2010) The Arabidopsis AP2/ERF transcription factor RAP2. 6 participates in ABA, salt and osmotic stress responses. Gene 457:1-12. DOI:10.1016/j.gene.2010.02.011

\section{Tables}

Table 1 Differentially expressed genes in the rice roots under different treatments. 


\begin{tabular}{|c|c|c|c|c|c|c|c|c|}
\hline \multirow[t]{2}{*}{ No } & \multirow[t]{2}{*}{ ID } & \multirow[t]{2}{*}{ Name } & \multicolumn{2}{|l|}{$\mathrm{Al}+\mathrm{S} / \mathrm{Al}$} & \multicolumn{2}{|l|}{$\mathrm{Al} / \mathrm{CK}$} & \multicolumn{2}{|l|}{$\mathrm{S} / \mathrm{CK}$} \\
\hline & & & $\log _{2}(\mathrm{fc})$ & $\begin{array}{l}p- \\
\text { value }\end{array}$ & $\log _{2}(\mathrm{fc})$ & $\begin{array}{l}p- \\
\text { value }\end{array}$ & $\log _{2}(\mathrm{fc})$ & $\begin{array}{l}p- \\
\text { value }\end{array}$ \\
\hline 1 & Os03t0197200 & Sorbitol transporter & 1.01 & 0.00 & NC & & NC & \\
\hline 2 & Os02t0576600 & Sucrose transporter & 1.87 & 0.01 & -2.10 & 0.00 & NC & \\
\hline 3 & Os10t0136200 & $\begin{array}{l}\text { Cyclin-like F-box domain } \\
\text { containing protein }\end{array}$ & 1.87 & 0.05 & NC & & NC & \\
\hline 4 & Os01t0729600 & $\begin{array}{l}\text { Pyridoxal phosphate- } \\
\text { dependent transferase }\end{array}$ & -3.25 & 0.00 & 3.08 & 0.00 & NC & \\
\hline 5 & Os04t0107600 & Arginine decarboxylase & -2.97 & 0.00 & NC & & NC & \\
\hline 6 & Os11t0116200 & $\begin{array}{l}\text { Nonspecific lipid-transfer } \\
\text { protein } 3\end{array}$ & -9.16 & 0.00 & NC & & NC & \\
\hline 7 & Os11t0427800 & $\begin{array}{l}\text { Nonspecific lipid-transfer } \\
\text { protein } 3\end{array}$ & -8.40 & 0.00 & NC & & NC & \\
\hline 8 & Os12t0115500 & $\begin{array}{l}\text { Nonspecific lipid-transfer } \\
\text { protein } 3\end{array}$ & -4.40 & 0.01 & NC & & -4.29 & 0.01 \\
\hline 9 & Os06t0260500 & 3-ketoacyl-CoA synthase & -7.64 & 0.00 & 7.64 & 0.00 & NC & \\
\hline 10 & Os03t0181500 & Beta-ketoacyl-CoA synthase & -7.23 & 0.00 & NC & & NC & \\
\hline 11 & Os03t0830800 & $\begin{array}{l}\text { Pectinesterase inhibitor } \\
\text { domain containing protein }\end{array}$ & 2.31 & 0.00 & NC & & NC & \\
\hline 12 & Os03t0845600 & Glycoside hydrolase & 1.93 & 0.05 & -2.10 & 0.00 & NC & \\
\hline 13 & Os05t0248200 & Glycoside hydrolase family 18 & -1.45 & 0.04 & 4.10 & 0.00 & NC & \\
\hline 14 & Os08t0482300 & Arabinogalactan protein 1 & -1.07 & 0.00 & NC & & NC & \\
\hline 15 & Os01t0937900 & Arabinogalactan protein 2 & -1.32 & 0.00 & NC & & NC & \\
\hline 16 & Os06t0184900 & Hydroxycinnamoyltransferases & -7.20 & 0.00 & NC & & NC & \\
\hline 17 & Os12t0227500 & $\begin{array}{l}\text { Beta-glucosidase aggregating } \\
\text { factor }\end{array}$ & -2.11 & 0.00 & NC & & NC & \\
\hline 18 & Os08t0501600 & Wall-associated kinase & 3.20 & 0.03 & NC & & NC & \\
\hline 19 & Os10t0103140 & Wall-associated kinase & 2.78 & 0.01 & NC & & NC & \\
\hline 20 & Os09t0368200 & Polyamine oxidase precursor & 2.72 & 0.05 & NC & & NC & \\
\hline 21 & Os08t0140500 & Tryptophan decarboxylase & 1.29 & 0.01 & -1.27 & 0.01 & NC & \\
\hline 22 & XLOC_035969 & $\begin{array}{l}\text { Cinnamoyl-CoA reductase 1- } \\
\text { like }\end{array}$ & 1.01 & 0.02 & NC & & NC & \\
\hline 23 & Os09t0451400 & ACC oxidase & -1.30 & 0.00 & NC & & NC & \\
\hline 24 & Os05t0210400 & $\begin{array}{l}\text { Lipase, GDSL domain } \\
\text { containing protein }\end{array}$ & -1.46 & 0.03 & 1.19 & 0.04 & NC & \\
\hline 25 & Os09t0567800 & $\begin{array}{l}\text { Lipase, GDSL domain } \\
\text { containing protein }\end{array}$ & -1.07 & 0.01 & NC & & NC & \\
\hline 26 & Os12t0111900 & $\begin{array}{l}\text { GCN5-like } 1 \text { domain containing } \\
\text { protein }\end{array}$ & 1.53 & 0.04 & NC & & NC & \\
\hline
\end{tabular}




\begin{tabular}{|c|c|c|c|c|c|c|c|}
\hline 27 & Os02t0644400 & Kinesin heavy chain & 1.33 & 0.00 & -1.89 & 0.00 & NC \\
\hline 28 & Os12t0154800 & Germin-like protein $12-2$ & 1.53 & 0.00 & NC & & NC \\
\hline 29 & Os08t0189400 & Germin-like protein 8-5 & 1.51 & 0.00 & NC & & NC \\
\hline 30 & Os08t0190100 & Germin-like proteins 8-11 & 1.46 & 0.00 & NC & & NC \\
\hline 31 & Os08t0189900 & Germin-like proteins 8-10 & 1.37 & 0.00 & NC & & NC \\
\hline 32 & Os12t0154700 & Germin-like proteins $12-1$ & 1.27 & 0.00 & NC & & NC \\
\hline 33 & Os08t0189850 & Germin-like protein8-9 & 1.18 & 0.00 & NC & & NC \\
\hline 34 & Os12t0155000 & Germin-like protein $12-4$ & 1.01 & 0.00 & NC & & NC \\
\hline 35 & Os07t0476900 & $\begin{array}{l}\text { Thioredoxin domain } 2 \\
\text { containing protein }\end{array}$ & 1.22 & 0.03 & NC & & NC \\
\hline 36 & Os02t0661000 & $\begin{array}{l}\text { Peroxisomal biogenesis factor } \\
19\end{array}$ & 1.07 & 0.00 & NC & & NC \\
\hline 37 & Os11t0189600 & Cycloartenol synthase & -6.32 & 0.01 & 3.00 & 0.04 & NC \\
\hline 38 & XLOC_032921 & $\begin{array}{l}\text { Benzothiadiazole-induced } \\
\text { protein }\end{array}$ & -1.45 & 0.00 & NC & & NC \\
\hline 39 & Os09t0507300 & L-ascorbate oxidase precursor & 1.35 & 0.01 & NC & & NC \\
\hline 40 & Os07t0475700 & $\begin{array}{l}\text { Auxin responsive SAUR protein } \\
\text { family protein }\end{array}$ & 2.81 & 0.03 & NC & & NC \\
\hline 41 & Os01t0768333 & $\begin{array}{l}\text { Auxin responsive SAUR protein } \\
\text { family protein }\end{array}$ & 2.54 & 0.03 & NC & & NC \\
\hline 42 & Os02t0143300 & $\begin{array}{l}\text { Auxin responsive SAUR protein } \\
\text { family protein }\end{array}$ & 1.10 & 0.03 & NC & & NC \\
\hline 43 & Os11t0514400 & $\begin{array}{l}\text { BRASSINOSTEROID } \\
\text { INSENSITIVE } 1 \text {-associated } \\
\text { receptor kinase } 1\end{array}$ & 7.44 & 0.04 & NC & & NC \\
\hline 44 & Os10t0489500 & Terpene synthase 2 & 7.38 & 0.00 & NC & & NC \\
\hline 45 & Os08t0168400 & Sesquiterpene synthase & 2.20 & 0.00 & NC & & NC \\
\hline 46 & Os06t0255400 & Nudix hydrolase 18 & 1.06 & 0.00 & NC & & 1.11 \\
\hline 47 & Os09t0376600 & Tyrosine protein kinase & -1.64 & 0.01 & NC & 0.01 & NC \\
\hline 48 & Os07t0692800 & $\begin{array}{l}\text { Eukaryotic translation initiation } \\
\text { factor } 2\end{array}$ & 3.14 & 0.00 & NC & 0.05 & NC \\
\hline 49 & Os07t0566800 & $\begin{array}{l}\text { Toll-Interleukin receptor } \\
\text { domain containing protein }\end{array}$ & 6.98 & 0.03 & NC & & NC \\
\hline 50 & Os09t0457900 & AP2/ERF transcription factor & 1.97 & 0.02 & NC & & NC \\
\hline 51 & Os07t0674800 & AP2/ERF transcription factor & 1.31 & 0.02 & NC & & NC \\
\hline 52 & Os09t0522100 & $\begin{array}{l}\text { Dehydration-responsive } \\
\text { element-binding protein } 1 \mathrm{H}\end{array}$ & 1.69 & 0.00 & NC & & NC \\
\hline 53 & Os09t0522200 & $\begin{array}{l}\text { Dehydration-responsive } \\
\text { element-binding protein } 1 \mathrm{~A}\end{array}$ & 1.66 & 0.00 & NC & & NC \\
\hline 54 & Os03t0860100 & Ethylene-responsive & 1.23 & 0.01 & NC & & NC \\
\hline
\end{tabular}

Page 18/24 
transcription factor 2

\begin{tabular}{|cllllll|}
\hline 55 & Os04t0547600 & ERF domain containing protein & 1.28 & 0.00 & NC & NC \\
\hline 56 & Os04t0667200 & Flavanone 3-hydroxylase 3 & 1.08 & 0.01 & NC & NC \\
\hline 57 & Os01t0127450 & MYBL2 & -2.44 & 0.04 & NC & NC \\
\hline 58 & Os03t0625300 & OsWD40-77 & -1.84 & 0.00 & NC & NC \\
\hline 59 & Os05t0337400 & $\begin{array}{l}\text { Heavy-metal-associated } \\
\text { domain-containing protein }\end{array}$ & -1.06 & 0.00 & NC & NC \\
\hline
\end{tabular}

There were three independent biological replicates for the transcriptomics analysis. The differentially expressed genes that changed more than $\log _{2}(\mathrm{fc}) \geq 1$ and passed Student's $t$-test $(P \leq 0.05)$ were defined as significantly different. The Al stress concentration in the solution was $30 \mu \mathrm{M}$, the NaHS concentration was $2 \mu \mathrm{M}$. CK: without Al and NaHS; Al: single Al treatment; S: single NaHS treatment; Al+S: both Al and NaHS treatment. NC: no change.

\section{Figures}
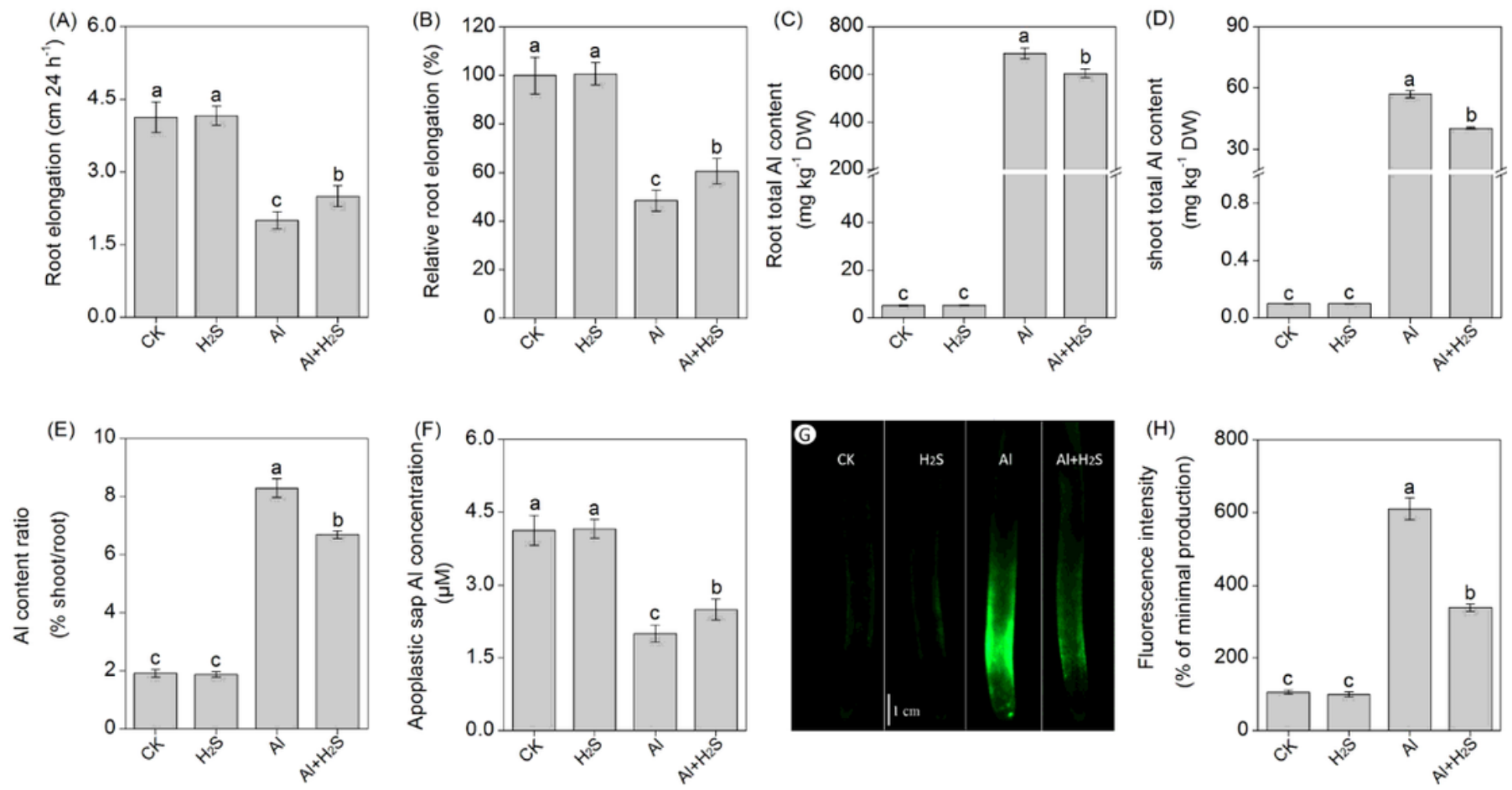

\section{Figure 1}

Effects of H2S on (A) rice root elongation, (B) relative root elongation, (C) root total Al content, (D) shoot total Al content, (E) shoot-root-Al-content ratio, (F) apoplastic sap Al concentration, (G) cytoplasm Al content (indicated by the intensity of green fluorescence after the rice roots were stained by morin regent), and $(\mathrm{H})$ the fluorescence intensity. Data are means \pm $S D(n=4)$. Columns with different letters are significantly different at $P<0.05$. 

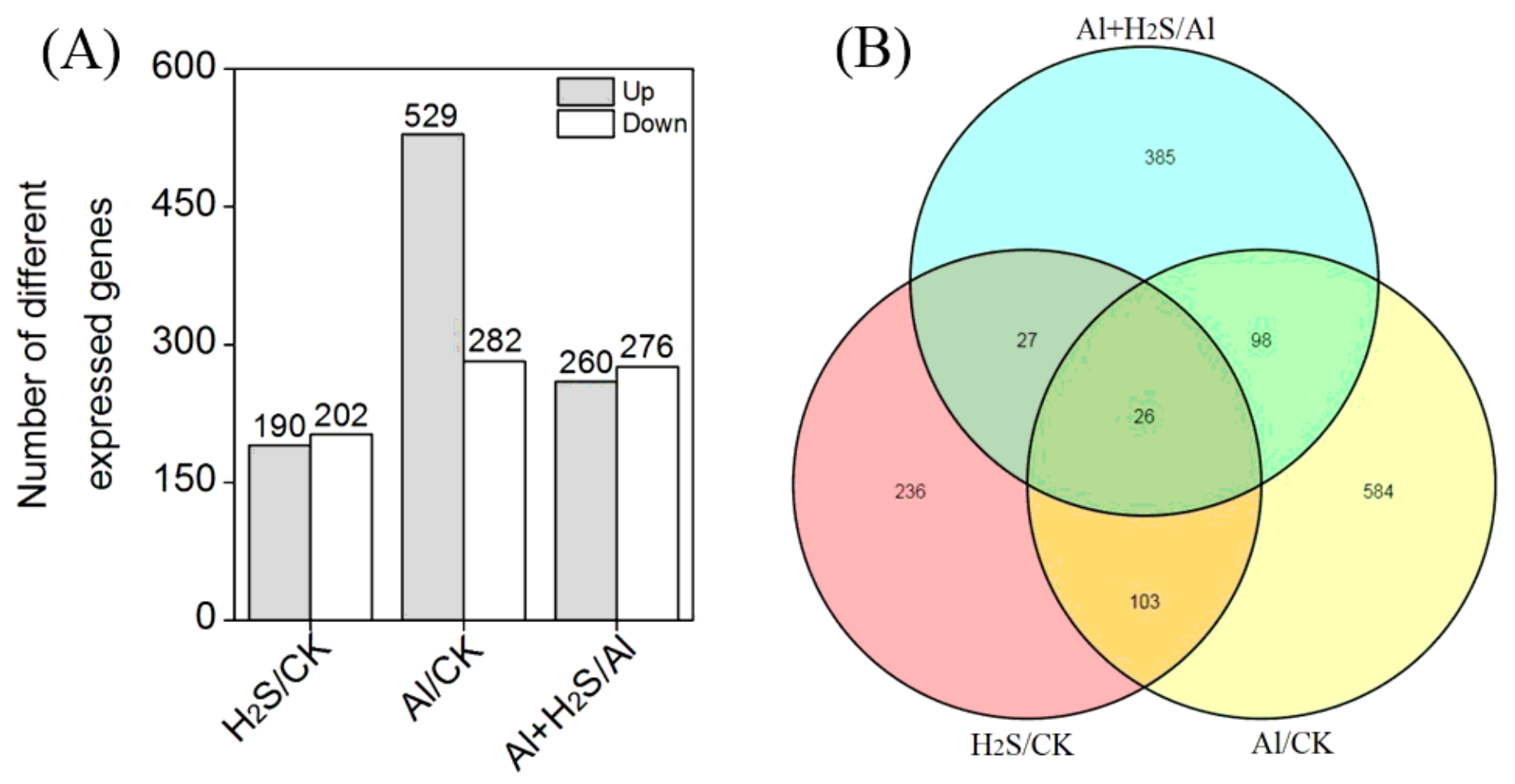

Figure 2

Number of differentially expressed genes (A) and (B) Venn diagram of all of the differentially expressed genes in the rice roots under different treatments. 

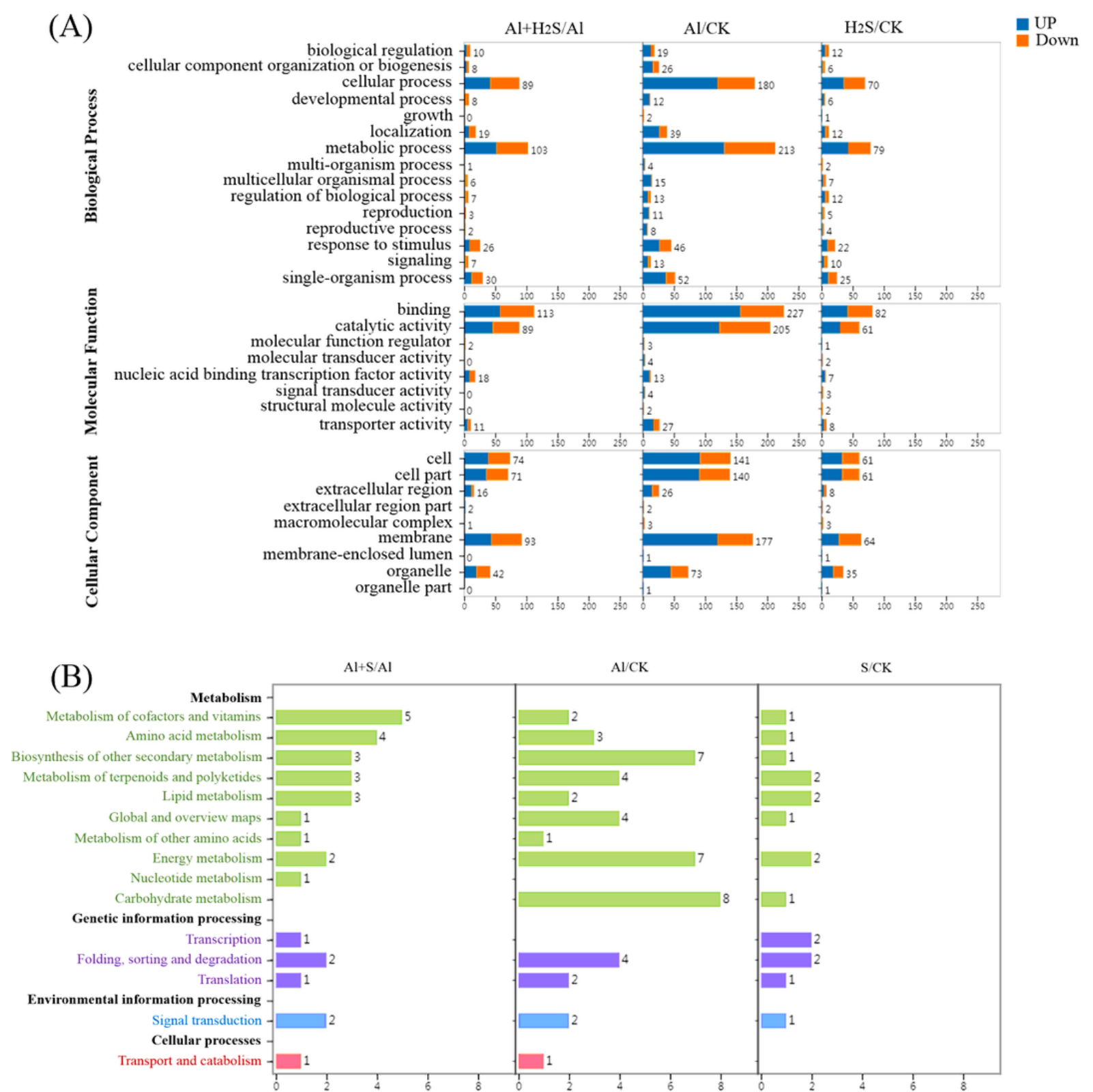

Figure 3

The Gene Ontology (GO) analysis (A) and (B) KEGG pathway annotations for all the differentially expressed genes in our study. 

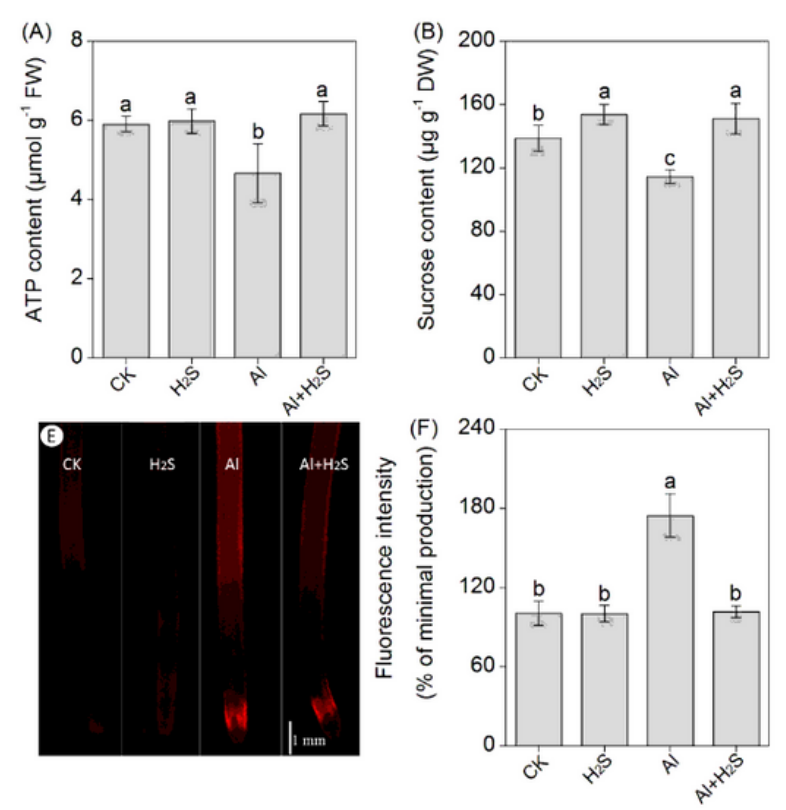
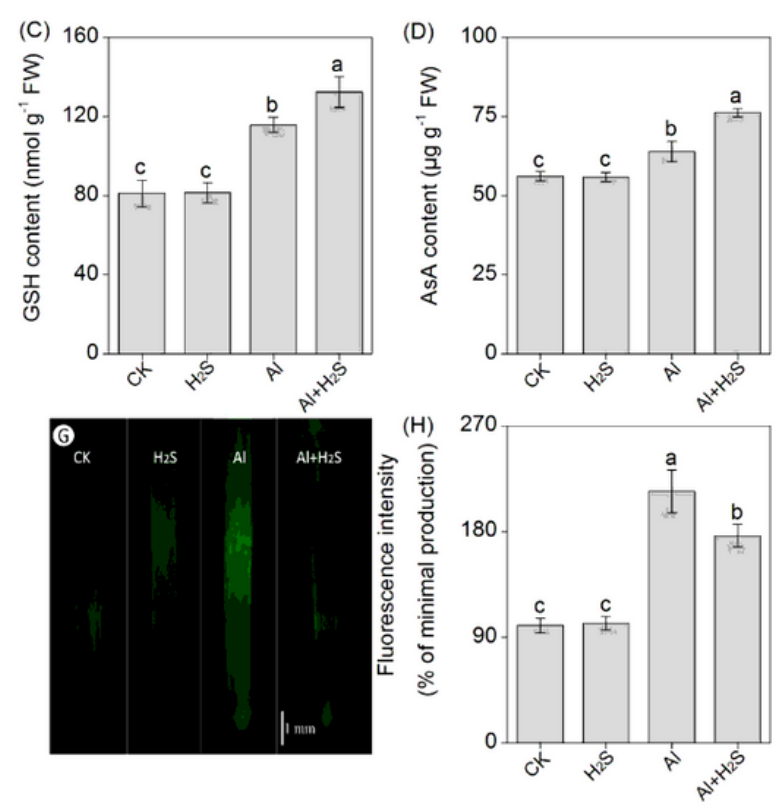

(I)
(0.61)
$(0.35)$
(0.41)
(0.49)
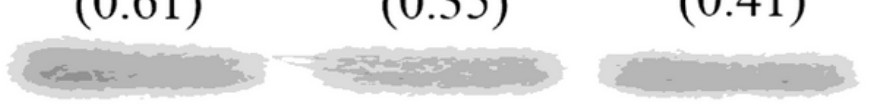
ATP synthase

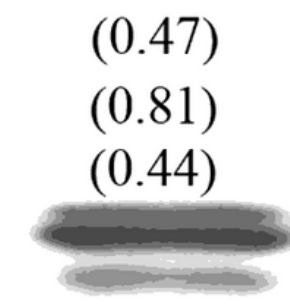

(0.35)

(0.61)

(0.19)

(1.27)

(0.41)

(0.51)

(0.69)

(1.05)

(0.23)

(0.23)

SAPX

pAPX

cAPX

(0.98)

\section{CAT}

\section{$\beta$-actin}

\section{CK \\ $\mathrm{H}_{2} \mathrm{~S}$ \\ Al \\ $\mathrm{Al}+\mathrm{H}_{2} \mathrm{~S}$}

\section{Figure 4}

Effect of 2- $\mu \mathrm{M}$ NaHS on the (A) sucrose content, (B) ATP content, (C) GSH content, (D) AsA content, (E-F) superoxide anion 02-- content, $(\mathrm{G}-\mathrm{H}) \mathrm{H} 2 \mathrm{O} 2$ content, and (I) protein abundance of ATP synthase, APXs, and CAT under different treatments in the rice roots. The $02 \cdot-$ and $\mathrm{H} 2 \mathrm{O} 2$ contents are indicated by the intensity of the red and green fluorescence, respectively. Data are means $\pm S D(n=4)$. Columns with different letters are significantly different at $P<0.05$. The values in (I) were calculated based on the gray value of the target protein compared with $\beta$-actin under each treatment. sAPX: stromal APX; pAPX: peroxisomal APX; cAPX: cytoplasmic APX. 

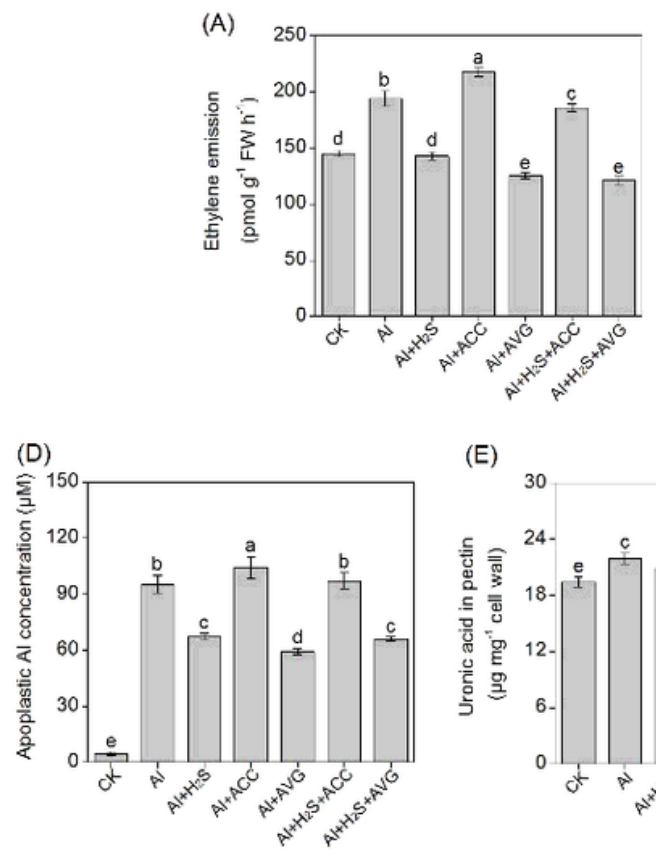

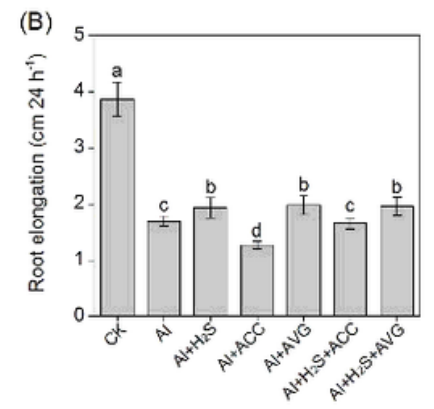

(E)

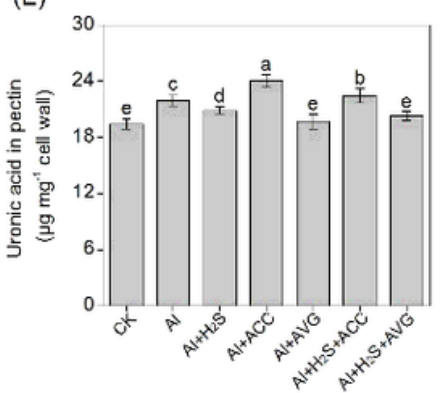

( $\mathrm{F}$
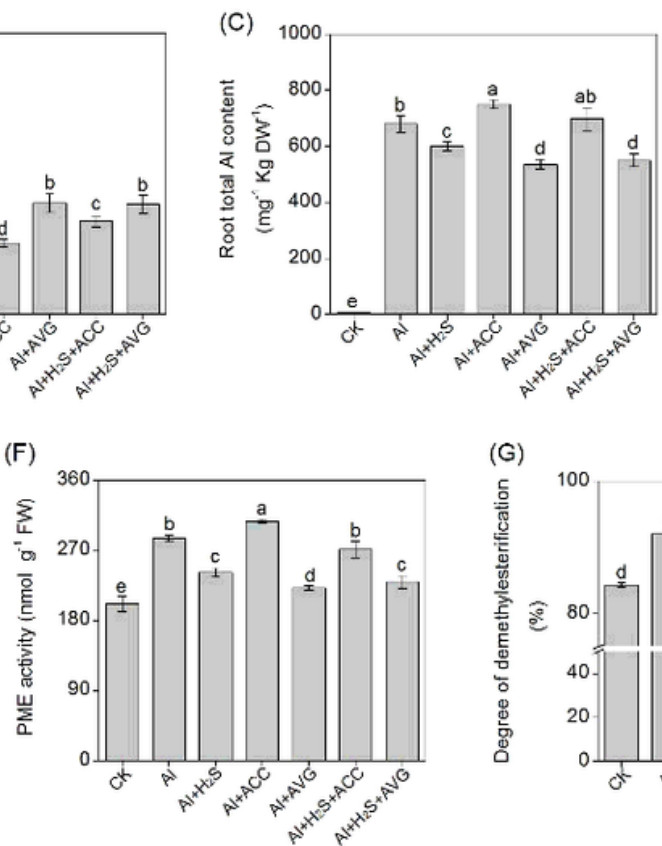

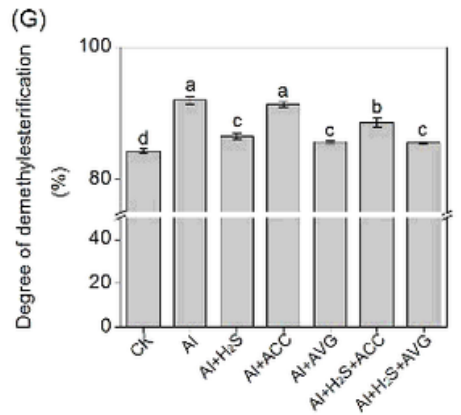

Figure 5

Effect of 2- $\mu \mathrm{M} \mathrm{NaHS}$ on the (A) ethylene emissions, (B) root elongation, (C) root total Al content, (D) apoplastic Al concentration, (E) pectin content, (F) PME activity, and (G) pectin demethylesterification degree in the rice roots. Data are means $\pm S D(n=4)$. Columns with different letters are significantly different at $P<0.05$. 


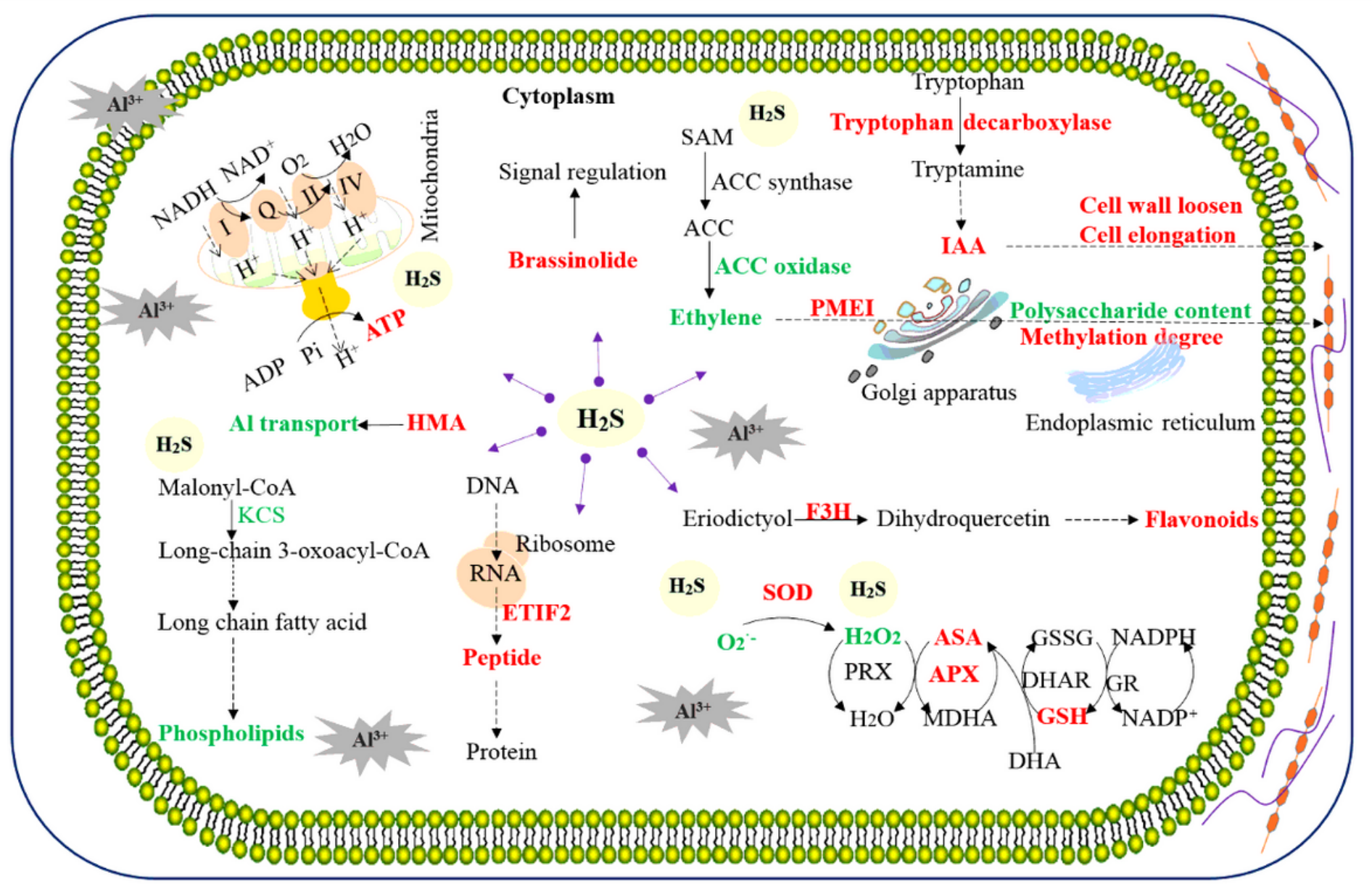

Figure 6

A schematic model for H2S-mediated improvement of root elongation under Al toxicity in rice. ACC: 1-

aminocyclopropane-1-carboxylic acid; ETIF2: eukaryotic translation initiation factor 2; F3H: flavanone 3-hydroxylase 3; HMA: heavy-metal-associated domain-containing protein; KCS: ketoacyl-CoA synthase; PMEl: pectinesterase inhibitor domain containing protein.

\section{Supplementary Files}

This is a list of supplementary files associated with this preprint. Click to download.

- Supplementarymateriials0621.docx 